\title{
SUNDANESE AHMADIYYA'S PUPUJIAN OF THE MAHDI IN WEST JAVA
}

\author{
Jajang A Rohmana
}

UIN Sunan Gunung Djati Bandung, Indonesia

E-mail: jajangarohmana@uinsgd.ac.id

\section{Abstract}

This article focuses on the local tradition of Ahmadiyya in West Java in the form of Sundanese oral literature entitled Pupujian Imam Mahdi, the song of praise of the Mahdi. It is not only related to strengthening the so-called "Sundanese Ahmadiyya" identity through cultural acculturation, but also an important channel in their acceptances in regions with the largest adherents in Indonesia. Through literary and cultural identity analysis, I argue that the literary and cultural channels contributed to the acceptance of minority groups in Indonesia. Through pupujian Imam Mahdi, for instance, Ahmadiyya teachings on the messianistic figure were acculturated into the Sundanese literary tradition. It becomes a frame of movement towards the formation of the Sundanese Ahmadiyah identity. The pupujian is used to support their existences through the same cultural representation as other Sundanese people. It is a cultural strategy carried out by the most controversial minority group among the rejection of the most groups. This study is also important in revealing Ahmadiyya's contribution to the Sundanese local culture which may not be recognized by others. It actually becomes a peculiarity of Ahmadiyya identity in the Indonesian archipelago which is different from other cultural representation of Ahmadiyya in various regions in the world.

Artikel ini memfokuskan pada tradisi budaya lokal di kalangan Ahmadiyah di Jawa Barat berupa sastra lisan Sunda Pupujian Imam Mahdi. Ia tidak 
dapat diabaikan, bukan hanya terkait penguatan identitas Ahmadiyah Sunda melalui akulturasi budaya, tetapi juga menjadi saluran penting dalam penerimaan mereka di daerah dengan jumlah penganut terbesar di Indonesia. Melalui analisis sastra dan identitas budaya, kajian ini menunjukkan bahwa saluran sastra dan budaya memiliki kontribusi dalam proses penerimaan ajaran kelompok minoritas di Indonesia. Melalui Pupujian Imam Mahdi misalnya, ajaran Ahmadiyah diakulturasikan ke dalam tradisi sastra Sunda dan dijadikan bingkai gerakan ke arah pembentukan identitas Ahmadiyah Sunda. Pupujian digunakan untuk mempertahankan eksistensinya melalui sistem representasi budaya yang sama dengan orang Sunda lainnya. Sebuah strategi budaya yang dilakukan kelompok minoritas paling kontroversial di tengah penolakan kaum mayoritas di Indonesia. Kajian ini juga penting dalam menyingkap sumbangan Ahmadiyah terhadap pelestarian kekayaan budaya lokal Sunda yang boleh jadi tidak diakui masyarakat Sunda lainnya. Sesuatu yang justru menjadi kekhasan identitas Ahmadiyah di Nusantara yang cenderung berbeda dengan bentuk strategi budaya Ahmadiyah lainnya di berbagai kawasan lain di dunia.

Keywords: Ahmadiyya; identity; messianism; pupujian; Sunda

Received: October 29, 2018; Accepted: September 18, 2019

\section{Introduction}

The Ahmadiyya community is one of the most controversial among the minority groups in Islam. The Ahmadiyya community claims to have more than ten million followers in the world. Most Ahmadis live in Pakistan, but a very significant number are found in Indonesia and West African countries such as Nigeria, Ghana, Sierra Leone, and Gambia. Ahmadiyya became a powerful transnational movement since the beginning of the twentieth century (Burhani 2013, 30). There is great attention of scholars on the problem of Ahmadiyya in Indonesia that studied from various perspectives (As'ad 2009, 390-413; Breidlid 2013, 165-77; Burhani 2014a, 141-58; Noor 2015, 135-64; Hasyim 2017, 211-33). The Ahmadis who lived in Indonesia as a country with the largest Muslim population in the world are Sundanese people. They mostly lived in West Java. They are still perceived as one of the minority groups that are "deviant and misleading community" (Alfitri 2008, 1-27; Hicks 2014, 321-39; Burhani 
2014b, 133-52). They received a terrible attack, especially after three Ahmadis brutally killed in Cikeusik Banten on February 6, 2011 (Scherpen 2015, 103-31).

The element of Indonesian civil society, such as NU and Muhammadiyah, tend to be in a "dilemma" in order to respond to the persecution of Ahmadiyya. These two largest mass organizations in Indonesia, on the one hand, respect the existence of the Ahmadiyya, but on the other hand strengthen the stigma of Ahmadiyya heresy. They are unable to stop the attack on the Ahmadiyya community in various regions in Indonesia. It is a response that is not directly proportional than both NU and Muhammadiyah's responses to the Christian minority groups. This is a choice of response that Menchik calls as a form of "tolerance without liberalism" (Menchik 2011, v).

However, although the Ahmadis were regarded as s deviant group by other Muslims, they could maintain their existences until now. Some scholars refer to a number of strategies carried out by the Ahmadiyya community, such as emotional, social, informal, ethics, and spirituality. They respond the sufferings and winning the hearts of their followers with following strategies: a fortitude based on faith and spirituality, more rationally understanding of the oppression, using ideological maneuvers, taking resistance actions, harmonizing identity and fulfilling everything needed (Connley 2016, 29-58; Burhani 2014c, 657-90; Soedirgo 2018, 191 207). Their strategies in managing social resilience face various external pressures to create a tolerant multi-religious community. It is a strategy considered as a capability in maintaining the Ahmadiyya position in Indonesian community (Pamungkas 2015, 251-78).

There is another strategy that has not been studied by scholars regarding the survival of Ahmadiyya and its acceptance in the Indonesian community. One of the important strategies is the channel of Sundanese literature. The Ahmadis use the traditional song of praise or pupujian (Javanese: syi'iran) to introduce the Mahdi and his teachings in West Java. This Ahmadiyya's song of praise, for example, can be seen in the lyrics "Pupujian Imam Mahdi Atos Lungsur" (the song of praise on The Mahdi has come) which I found in the Ahmadiyya community in Tasikmalaya and Kuningan. I obtained the pupujian when interviewed one of the Ahmadiyya followers, Mr. B (pseudonym), in Manislor, Kuningan (Friday, 11/27/2015, 09:30 a.m.). I also confirmed the pupujian at several Ahmadiyya mosques in 
Singaparna, Tasikmalaya. Pupujian is Sundanese oral literature usually sung in mosques before the time of prayer (Rusyana 1971,1). The song of praise on Imam Mahdi cannot be ignored in strengthening the ideological roots of Ahmadiyya in an area with the largest number of its followers in Indonesia (Sofianto 2014, 172).

The article is important to uncover the heritage of Sundanese literary and oral tradition that spread among the Ahmadiyya community. It may be considered less important by other Sundanese Muslims. This study may add another viewpoint of the Ahmadiyya which is no longer seen as the other who limited into the framework of orthodoxy and heterodoxy of Islam. The self-representation of the Ahmadiyya teachings reject the opinion of its heterodoxy (Lathan 2008, 388). I will show Ahmadis' experience sharing their religious identities with non-Ahmadis which do not break away from the wealth of local culture. The Sundanese Ahmadiyya should add to the variety of categorization of contexts regarding the identity of Ahmadiyya movement contributing to peaceful and productive coexistence in Indonesia (Del Re 2014, 115-31).

In addition, in the context of Ahmadiyya studies, this study also provides another perspective on the study of cultural strategies among the minority groups in Indonesia. The term of the religious minority in Indonesia does not only refer to non-Muslim, but also the Ahmadiyya community. Even after the decline of New Order in 1998, the response of Islamic organizations in Indonesia towards the Ahmadiyya community generally tends to be worse than that of non-Muslim (Burhani 2014d, 287). Therefore, this study will highlight the response of the Ahmadiyya community as a minority group through the song of praise on the Mahdi or pupujian Imam Mahdi. The Ahmadis use this Sundanese culture strategy in order to maintain their existences as a minority group in the midst of hatred responses to them.

\section{Sundanese pupujian in West Java}

It has not been known when the Sundanese song of praise or pupujian spread in Sundanese society. Its emergence as an oral tradition at pesantren (traditional Islamic boarding schools) cannot be separated from the influence of Islam in the sixteenth century. There are similarities in the lyrics of pupujian in various places in West Java. It demonstrates the strong relationship between Islamic scholars or kiais and their students (santris) 
who are connected with the network of pesantren in Indonesian archipelago or Nusantara (Rohmana 2015a, 175-202).

The santris generally will settle in the Sundanese communities after completing their studies at several pesantrens. They become Islamic teachers or imam of the mosque as well as establish a new pesantren. Pesantren as a center for Islamic education prioritizes the religious teaching, the formation of Islamic character, and various skills of santri in order to be own master. Its position as a sub-culture can be seen from the role of pesantren in the dissemination of cultural element. One of these cultural elements is the work of religious literature that become teaching materials of kitab kuning at pesantren (Manshur 1999, 108). This religious literature plays a role in local cultural preservation, as well as developing resources of the pesantren community. The local culture at pesantren consists of oral and writing literary traditions, semi-ritual traditions, the art of self-defense (penca, pencak silat), and theatrical traditions including music and performances (Romli H.M. 2005, 151). The collective culture of pesantren is generally living in the Nahdlatul Ulama (NU) community, which usually easy to accept the influence of art culture, both from pre-Islamic and Arabic traditions through the development of popular arts and culture (Rasmussen 2010, 23).

The song of praise or pupujian is one of the Sundanese oral traditions that is usually sung at the mosque before the prayer. According to data from 1982, there were 32 thousand mosques in West Java (Syaqiq 2009 , 3). The pupujian is often sung every day, especially when waiting for the prayer time at the mosque between adhân and iqâmah. Some pupujians are also often sung in the commemoration of Prophet Muhammad's birthday (mawlid), the wedding ceremony, or used to accompany the performance of pencak silat which is played with a musical instrument, such as terebangan and genjringan. The song of praise or pupujian is one of the elements that distinguishes secular Sundanese performance art that is based on regional folk songs with Islamic art that developed at pesantren (Patzold 2011, 172, 185-6). The pupujian as well as marhaba, rudat, kasidahan, tagoni, genjring terebang, Cigawiran, and others, are Islamic art tradition that enriches the heritage of literary and performing arts of Sundanese Islam in West Java (Rosidi 2011, 90; Nurjamin 2005, 158).

The pupujian as one of Sundanese literature forms is generally contains advice, prayer, education, and religious praise. There are usually 
various kinds of pupujian which have similarities in West Java, such as pupujian nabi urang sadayana (song of praise of our prophet), éling umat, éling dulur kabéh ( $\mathrm{O}$ ye ummah, please remember!, $\mathrm{O}$ ye brothers, please remember!), the children of adam, etc. These kind of praises are also often called as nadoman, because of the large number of stanzas like Arabic poetry or shi'r. The nadoman sometimes also uses Arabic metrical verses. The Javanese pesantren often calls the nadoman as syitiran. The pupujian or nadoman practically can be a kind of religious entertainment, as well as conveying and caring for religious values in the form of singing that easily memorized.

Sundanese poetry and song of pupujian contain praise, prayer, advice, and education of Islam which can be sung. The pupuiian is not only using Sundanese language but also Arabic (Rosidi 2011, 11). The rules of poetry in pupujian do not different like Arabic poetry that has an influence on ruba'i of Persia literature and Malay poetry (Ma'mun 2011, 147-59; Rohmana 2015b, 9). Following poetry of pupujian is an example of the comparison between Arabic and Sundanese poetry (Romli H.M. 2005, 152):

Table 1

Arabic shi'r and Sundanese pupujian

\begin{tabular}{|c|c|}
\hline Arabic shi' $r$ & 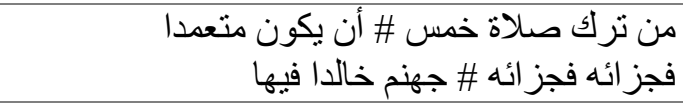 \\
\hline Sundanese pupujian & $\begin{array}{l}\text { Saha jalma tinggal kana solat, } \\
\text { Lima waktu tur dihaja, } \\
\text { Mangka dibales, mangka dibales, } \\
\text { Dilanggengkeun di naraka jahanam. }\end{array}$ \\
\hline English translation & $\begin{array}{l}\text { Those who leave of prayer, } \\
\text { for five times intentonally, } \\
\text { he/she will be punished, } \\
\text { perpetuated in hell. }\end{array}$ \\
\hline
\end{tabular}

The influence of Arabic shi'r on the tradition of Sundanese pupujian cannot be separated from the Islamic knowledge tradition at pesantren in Indonesian archipelago. It is closely related to the kitab kuning tradition of pesantren which are mostly composed using Arabic poetry in the form of shi'r 
and nazam in rhythmic poems, such as Alfiyah, Fath Rabb al-Bariyyah or popularly known as Imritîi, Hall al-Ma'qûd min Naz̧m al-Maqsûd or Yaqûlû, Kifâyat al-Atqiyâ' wa Minhâj al-Asfiyâa', Nûr al-Zalâm, Lamiyat al-Af'âl, Tuhfat alAhbâb, and others. Kitab kuning or Islamic books that learned at Javanese and Sundanese pesantrens are usually translated into Javanese, Sundanese or Madurese. The pattern of these translations written in the hang script of pegon (logat gantung). It is generally known as the book of janggotan or gandul (Heryani 2005, 174). K.H. Ahmad Makki, for instance, was known as one of the chief of pesantren who productively published Sundanese translation of kitab kunings in West Java. He has published about 70 titles of kitab kunings into the Sundanese pegon script through the publisher of AlSalafiyah Sukabumi, some of the publications using the form of Arabic nazam (Yahya 2009, 368, 374; 2008, 85). He follows the productivity of Ahmad Sanusi, a charismatic 'ulama' from pesantren of Gunungpuyuh Sukabumi who published many Islamic works in the period of the 1930s (Matin 2009, 147-64). The variety of kitab kunings of pesantren have long influenced the development of similar texts of nazam in Sundanese, which became known as Sundanese pupujian.

The translation of Arabic nazam at some pesantrens is also adapted into so-called as nadoman or Sundanese pupujian. Some 'ulama's published their Islamic works in the form of Sundanese pupujian written in pégon script. Ahmad Dimyati, a chief of pesantren Sukamiskin, for instance, adapted the book of Sharaf al-Anâm. Another Sundanese 'ulama' is Asep Saepudin, chief of pesantren Cilember, who translated Nazam Adhkiyâa' into Sundanese language entitle Sawaréh Barzanji (Ma'mun 2009, 235-52). Some of the pégon literary works were also written and published with lithograph printing by the 'ulama' of pesantrens, such as Shi'r al-Hisân fî Tafâsîl Mawlid Sayyid al-Ins wa al-Jânn by Haji Muhammad Juwayni bin Haji 'Abdurrahman (Jakarta: Shirkah Ali Rida, n.d.). The translations in the form of Sundanese pupujian are usually read and sung together in religious events such as Muludan, Marhabaan, Salawatan, and others.

Other Sundanese publications on pupujian was also written by Moh. Koerdi who has published a small book entitled Pupujian in 1929. Several pupujians also was written by Enas Mabarti which was published in Mangle magazine. Both works of Moh. Koerdi and Enas Mabarti, as well as other works of pupujian, are then republished by Ajip Rosidi (Rosidi 2011). However, the most valuable contribution in the publication of Sundanese 
pupujian is the inventory of Yus Rusyana on pupujian in several districts in West Java in 1970. The pupujian which sung and learned in the Sundanese community generally were documented in Rusyana's work.

The song of praise or pupujian is generally following the rules of poetry in the form of the number of cantos (larik), the number of syllables, and the scheme of ending vowels in each stanza. The number of cantos usually consists of two, four, six to nine arrays in each stanza. Meanwhile, the number of syllables in each canto is multiple diverse. It usually consists of eight, ten, twelve to fourteen syllables. The scheme of ending vowels in each stanza generally uses the same ending vowel (a-a-a-a), although sometimes there are also two alternating different vowels (a-b-a-b, a-a-b-b) (Rusyana 1971, 14-6).

Following Sundanese pupujians usually sang at mosques in West Java (Rusyana 1971, 21, 27, 39):

Table 2

Sundanese pupujians

\begin{tabular}{|c|c|}
\hline Sundanese pupujian & English translation \\
\hline $\begin{array}{l}\text { Eling-éling dulur kabéh (8e) } \\
\text { Ibadah ulah campoléh (8e) } \\
\text { Beurang peuting ulah weléh (8e) } \\
\text { Bisina kaburu paéh (8e) } \\
\text { dst... }\end{array}$ & $\begin{array}{l}\text { Brothers, please remember!, } \\
\text { do not disparage your prayer, } \\
\text { it should be doing day and night, } \\
\text { before you die. } \\
\text { and so on... }\end{array}$ \\
\hline $\begin{array}{l}\text { Anak Adam anjeun di dunya ngumbara } \\
\text { (12a) } \\
\text { Hirup anjeun di dunya téh moal lila (12a) }\end{array}$ & $\begin{array}{l}\text { O ye the children of Adam, you } \\
\text { roam in the world, } \\
\text { your life is very short. }\end{array}$ \\
\hline $\begin{array}{l}\text { Anak adam umur anjeun téh ngurangan } \\
\text { (12a) } \\
\text { Saban poé saban peuting dicontangan (12a) } \\
\text { dst... }\end{array}$ & $\begin{array}{l}\text { O ye the children of Adam, your } \\
\text { age is lessen } \\
\text { lessened every day and night. } \\
\text { and so on... }\end{array}$ \\
\hline $\begin{array}{l}\text { Eling-éling umat (6a) } \\
\text { Muslimin muslimat (6a) } \\
\text { Hayu urang solat (6a) } \\
\text { Berjamaah "isya/magrib/subuh" (6i/a/u) }\end{array}$ & $\begin{array}{l}\text { O ye ummah, please remember! } \\
\text { the Muslims and muslim women, } \\
\text { let us perform the prayer together, } \\
\text { "'ishā'/maghrib/șbh," }\end{array}$ \\
\hline
\end{tabular}




$\begin{array}{ll}\text { Eta kawajiban (6a) } & \text { this is an Islamic obligatory, } \\ \text { Urang keur di dunya (6a) } & \text { our obligatories in the world, } \\ \text { Kanggo pibekeleun (6eu) } & \text { for our provisions, } \\ \text { Urang jaga di aherat (6a) } & \text { in the hereafter. } \\ \text { dst... } & \text { and so on... }\end{array}$

The pupujian contains Islamic advice and teachings. It is not Sundanese poetry with personal expression in the form of sadness, worry, concern, yearning, and others. It is different with the metrical verse of Sundanese dangding or guguritan. The dangding works of Haji Hasan Mustapa (1852-1930), for instance, dominated by personal expression in the form of sufistic experiences that reflect his yearning in pursuing the self-authenticity, from spiritual searching to achievement (Rohmana 2013, 325-75). Likewise, the dangding works of Wiranatakoesoema in the form of translation of the Quran (Rohmana 2015c, 439-467). Therefore, I agree with Rusyana who quotes Edmund Burke calling Sundanese pupujian as religious art, not spiritual art or art of spiritual concern (Rusyana 1971, 8).

Therefore, the pupujian is a Sundanese song that specifically teaches Islamic matters arranged in the form of poetry. It generally spreads long after the religion of Islam influenced the Sundanese people in West Java. The spread of pupujian cannot be separated from the role of mosques and pesantrens. The pupujian is an oral tradition spread verbally in Sundanese community and then memorized by santris. Therefore, there are many pupujians relatively similar in various pesantrens and mosques in Sunda regions. This illustrates the existence of religious networks among the santris and mosques at Sundanese pesantrens in the area now known as West Java.

There is an influence of Arabic language in the Sundanese pupujian. It is not only the Arabic vocabulary but also its structure of the sentence. In addition, the authors of pupujian mostly are not expert in Sundanese language. It can be seen, for instance, in Sundanese word that is often used repeatedly by the authors in their pupujians. Many Sundanese words are actually not appropriate to use, because there are many Sundanese vocabularies which are more precise. This weakness of Sundanese pupujian is understandable because most the author studied at pesantren where Sundanese language is only used as an oral communication to understand the kitab kuning. There are not many Sundanese pesantrens that have 
libraries where served collections of Sundanese books (Rosidi 2011, 89-90). Sundanese language as a medium for literary and cultural activities does not become a discourse that lives at Sundanese pesantrens. Therefore, it can be said that the 'ulama' of pesantren does not participate in Sundanese cultural preservations (Rosidi 2009, 71-2). This also may not be separated from the role of the Dutch colonial who deliberately distanced the pesantren community from the activities of Sundanese culture. It then was taken over by ménak or local elite community (Yahya 2003, 279-81). However, it cannot be denied that pesantrens have a major contribution in reviving Sundanese language as a medium of their religious activities.

The pupujian then also developed among the Ahmadiyya community. This Sundanese literature of pesantren also acculturated with the Ahmadiyya teachings. Sundanese people who had already known the pupujian at mosques got their religious aesthetic channel when they entered the Ahmadiyya community learning the Ahmadiyya's pupujian. Likewise, according to the author of Ahmadiyya's pupujian, there was an effort to harmonize the teachings of the Ahmadiyya with the richness of Sundanese culture and literature. The compilation of Ahmadiyya's pupujian, as will be explained, is carried out by Sundanese cultural experts from the Ahmadiyya community as an important channel for the cultivation of Ahmadiyya teachings for its majority members who are Sundanese people.

\section{The Mahdi in Ahmadiyya}

Ahmadiyya was founded in 1889. The founder of the Ahmadiyya movement was Mirza Ghulam Ahmad (1836-1908). He was born in Qadian, India on February 13, 1835. He then died in Lahore on May 26, 1908. He was descendant of Persian. His grandfather Mirza Hadi Beg fled from Samarkand to India during the ruler of Babar in the sixteenth century. The founding time of the Ahmadiyya movement was based on the time when the followers of Ahmadiyya take an oath to Ghulam Ahmad for the first time. The place of an oath was not in Qadian, but in Ludhiana, India on March 23, 1889. One of the followers who takes the oath is Hakeem Nuruddin, a close friend of Ghulam Ahmad who later became the first successor or caliph.

There are other names associated with the Ahmadiyya movement pejoratively, such as the Mirzaiyyah referring to the first name of Mirza Ghulam Ahmad, and the Qadianiyyah which refers to the place where the 
movement was founded. The use of the Qadian name is based on the distinction of the name with the other Ahmadiyya branch, the Ahmadiyya Lahore. Ahmadiyya Qadian, as a religious organization, uses the name of Ahmadiyya Muslim Jama'at (AMJ) or Ahmadiyya Muslim Community, while the Ahmadiyya Lahore uses the name of Ahmadiyya Anjuman Ish'at Islam Lahore (AAIIL) (Lathan 2008, 377). In Indonesia, Ahmadiyya Qadian uses the official name of the Jemaat Ahmadiyah Indonesia (JAI) or Indonesian Ahmadiyya Community, while the Ahmadiyya Lahore uses the name of the Gerakan Ahmadiyah Indonesia (GAI) or Indonesian Ahmadiyya Movement.

The clash and cleavage between Ahmadiyya Qadian and Lahore began after the death of Ghulam Ahmad in 1908. Hakeem Nuruddin was elected as the first Caliph who succeeded Ghulam Ahmad. Although there is no cleavage during Hakeem Nuruddin's period, there was an initial conflict in the Ahmadiyya movement. The conflict within the Ahmadiyya community occurred at its height after the death of Nuruddin or precisely during the second Caliph election in 1914. The conflict at the beginning of the clash among the Ahmadiyya community was very hard. The Ahmadiyya Lahore gradually became close to Sunni Islam and declared itself a da'wah organization. Meanwhile, Ahmadiyya Qadian creates a distinctive belief that is very different from the Lahore and majority of Muslims. These two Ahmadiyya groups have different teaching perspectives, especially in the prophecies of Ghulam Ahmad, the system of the caliphate, the election of the caliphate and the way to spread the teachings of Ahmadiyya (Wilar 2015, 165-80). This study will focus on the teaching of Ahmadiyya Qadian or JAI on the Mahdi that spread in Sundanese Ahmadiyya community in West Java.

There are controversial issues in the doctrines of Ahmadiyya different from the majority of Muslim beliefs. Some issues were deliberately created by the enemies of Ahmadiyya to blame them, such as their beliefs that Ahmadiyyah has own distinctive Islamic creed or shahâdah, the Qadian as hajj place, and tadhkirah as their own holy book. These accusations are mostly not based on facts, but only myths. The Ahmadiyya community has some different teachings that they generally admit themselves. One of their teachings is the doctrine of the Mahdi.

The doctrine of the Mahdi or Mahdiism generally cannot be separated from the Ahmadiyya beliefs on a better life tomorrow. It is related to the existence of a promising hope for its adherents and followers. They 
believe that there are promises and hopes that will bring peace in facing difficult situations. The suffering of life when cannot get a hope will lead to desperateness. It needs a solution facing a situation that can bring optimism to lead a future life.

Mahdiism or messianism is part of the hope that the religious movement offers to their followers. Mahdiism has long been a part of the tradition of Islamic movements characterized by different patterns. The various difficulties of Muslims have become one of the determinant factors of the Mahdiism. The European invasion of the Islamic world, for instance, was one of the historical periods that marked the emerging of Mahdi movement in the Muslim world, such as the anti-colonialism of Mahdi movement in West Africa and Sudan. The concept of Mahdi is one of the Muslims response to their defeats against the European nations. The Muslims believe that the Islamic decline is proof of the truth of Islamic teachings about the signs of the end of the world. One of these signs is the appearance of the Mahdi (Nasr 1987, 81).

Mahdiism is not only developed among Sunnis community. This concept also developed in the Shi'i community for a long time. According to Rahman, this kind of messianic belief is not genuine in Islam. It could be influenced by Christian mainly into the Shî'a (Rahman 1997, 191-2). Both Sunnîs and Shî'as have a similar belief for about the existence of the Mahdi. They are waiting for the emergence of charismatic figures who declare themselves as al-Mahdî or his representatives who are directly related to God and show a divine intervention into history.

In addition to Sunnis and Shi' as communities, the doctrine of the Mahdi has an important position in the teachings of the Ahmadiyya. The Ahmadiyya community as an Islamic school of thought and movement centered in India emphasizes ideological and eschatological aspects of Mahdiism based on the belief that al-Mahdî is a peace-maker for all differences of humankind (Azra 2005, x). The teaching of the Mahdi almost has the sameness to both Ahmadiyya Qadian and Lahore, but it has differences with the concept of the Mahdi among Sunnîs.

The concept of the Mahdi in Ahmadiyya is closely related to the coming of Jesus before the Day of Judgment. Both the Mahdi and Jesus are believed to be the same person. His job is to fight the Antichrist and destroy the cross. He was sent by God without bringing new teachings at all and only continued the teachings of Muhammad (Zulkarnain 2005, 83-4). This viewpoint is different from the beliefs of Muslims majority. All Muslims in 
the world, both Sunnî and Shî'a, generally agree that Jesus, the son of Mary or the Messiah, will come again. The Sunnîs argued that 'Isâ al-Masîh, who will come in the last times was Jesus, the son of Mary. He had been sent to the Children of Israel. 'Isâ al-Masîh is now considered alive in the heavens. He will go down to the world on the last times with the help of the Mahdi. 'Isâ al-Masith and the Mahdi are different persons. Both of them will fight against the Dajjal and non-Muslims until they convert to Islam. Islam then will achieve its glory again. According to the Ahmadiyya, both the Mahdi and the Messiah are believed to be in Mirza Ghulam Ahmad's self with the title al-masîh al-maw'î̀ (al-Masih who was promised).

This Ahmadiyya belief on the Mahdi in several regions in West Java were then spread in the form of Sundanese oral literature of song of praise or pupujian. This Sundanese oral literature that initially appears at pesantren has acculturated with the teachings of the Ahmadiyya. The Sundanese people who had already known the pupujian at mosques got their religious aesthetic channel when they followed the Ahmadiyya teachings and were taught the song of praise of the Ahmadiyya.

\section{Sundanese Ahmadiyya's Pupujian of the Mahdi}

With the above statement, Sundanese literature in the form of pupujian was originally part of the Islamic teaching that sung at mosques before the prayer (Rusyana 1971, 1). It was then used as a medium of Islamic learning at Ahmadiyya's mosques and schools, especially on the figure of the founders of the Ahmadiyya movement, Mirza Ghulam Ahmad. The Ahmadiyya community compiled the lyrics of their own song of praise or pupujian which contained the teachings of the Ahmadiyya. I found the Ahmadiyya's pupujian was sung by some Ahmadiyya communities in West Java, such as Singaparna Tasikmalaya, Garut, and Manislor Kuningan. This pupujian as a Sundanese oral literary tradition before the prayer was used in the teaching of Ahmadiyya. Therefore, both the teachings on the Mahdi and Mirza Ghulam Ahmad were then no longer considered different and merely on the surface, but acculturated deeply and merged into the life of the Sundanese Ahmadis.

Following pupujian is one of the popular of pupujians in the Sundanese Ahmadiyya community entitle Pupujian Imam Mahdi Atos Lungsur (the song of praise on The Mahdi has come). I found the Ahmadiyya's pupujian after interview one of the Ahmadiyya followers, Mr. 
B, in Manislor Kuningan (Friday, 11/27/2015, at 09:30). The pupujian also posted on the walls of the Ahmadiyya mosque in Singaparna. Following pupujian can be found among the Ahmadiyya community in Singaparna Tasikmalaya, Garut and Manislor Kuningan with several versions:

Table 3

Ahmadiyya's Pupujian

\begin{tabular}{|c|c|}
\hline Imam Mahdi Atos Lungsur & The Mahdi has come \\
\hline $\begin{array}{l}\text { Héy dulur-dulur sadaya } \\
\text { Poma ulah rék sulaya } \\
\text { Imam Mahdi atos aya } \\
\text { Tos lungsur ka alam dunya }\end{array}$ & $\begin{array}{l}\text { O ye all brothers, } \\
\text { do not broke faith, } \\
\text { the Mahdi has come, } \\
\text { He has come to the world. }\end{array}$ \\
\hline $\begin{array}{l}\text { Jenenganna nu ka masyhur } \\
\text { Turunan para luluhur } \\
\text { Hazrat Mirza Ghulam Ahmad } \\
\text { Neraskeun Nabi Muhammad }\end{array}$ & $\begin{array}{l}\text { His name has well-known, } \\
\text { He is the descendant of ancestors, } \\
\text { Hazrat Mirza Ghulam Ahmad } \\
\text { He is a successor of Prophet } \\
\text { Muhammad. }\end{array}$ \\
\hline $\begin{array}{l}\text { Nya anjeunna nu neraskeun/nyebarkeun } \\
\text { Islam teras disebarkeun/ditablighkeun } \\
\text { Sangkan nyiar/disebarkeun ka sadunya } \\
\text { Dipilampah enya-enya }\end{array}$ & $\begin{array}{l}\text { He who goes on/spreading } \\
\text { Islam then spread/preach } \\
\text { in order to spread to the world } \\
\text { carry out with devotion }\end{array}$ \\
\hline $\begin{array}{l}\text { Sanajan dipikangéwa } \\
\text { Mikaceuceub mikacua } \\
\text { Nyieun fitnah ngahalangan } \\
\text { Ahirna éra sorangan }\end{array}$ & $\begin{array}{l}\text { Despite being hated } \\
\text { displeased, disliked } \\
\text { making slander and block } \\
\text { finally, they embarrassed themselves }\end{array}$ \\
\hline $\begin{array}{l}\text { Sanajan di Dajjal-dajjal } \\
\text { Tapi Allah sifat Jalal } \\
\text { Tara jalir ti jangji-Na } \\
\text { Ngunggulkeun para rasul-Na }\end{array}$ & $\begin{array}{l}\text { Although it is called the Antichrist, } \\
\text { but Allah is Great, } \\
\text { He never disobeyed from His promise, } \\
\text { favor of His messengers. } \\
\text { (this stanza was not found in pupujian } \\
\text { of Ahmadiyya Manislor) }\end{array}$ \\
\hline Anggur mah héy dulur-dulur & It is more better, brother, \\
\hline
\end{tabular}




\begin{tabular}{ll}
\hline $\begin{array}{l}\text { Ulah waka langsung saur } \\
\begin{array}{l}\text { Mendingan/sumangga urang diajar } \\
\text { Sangan hirup/urang pada jembar }\end{array}\end{array}$ & $\begin{array}{l}\text { do not judge first, } \\
\text { let's learn first, } \\
\text { in order to live/our lifes in broad } \\
\text { minded. }\end{array}$ \\
\hline $\begin{array}{l}\text { Hayu urang pada ngabdi } \\
\text { Nuturkeun ka Imam Mahdi } \\
\text { Lebet kana Ahmadiyah } \\
\text { Malar karidhoan Allah }\end{array}$ & $\begin{array}{l}\text { Let's all serve, } \\
\text { following the Mahdi, } \\
\text { following Ahmadiyya, } \\
\text { hoping for the pleasure of God. } \\
\text { (this stanza was not found in pupujian } \\
\text { of Ahmadiyya Manislor) }\end{array}$ \\
\hline $\begin{array}{l}\text { Ieu abdi sadayana } \\
\text { Miwah réréncanganana }\end{array}$ & $\begin{array}{l}\text { Here we are, } \\
\text { with friends, } \\
\text { Mabarkeun sakapendakna }\end{array}$ \\
spread that gained, \\
it may be beneficial. \\
(this stanza was not found in pupujian \\
of Ahmadiyya Singaparna)
\end{tabular}

I interviewed Mr. R in Pataruman Garut (Tuesday, 08/16/2016 at 11.00). He said that Pupujian of "the Mahdi has come" was compiled by his grandfather, Sadkar, an Ahmadiyya activist as well as a Sundanese cultural observer who has been chief of Dinas Kebudayaan Garut or Garut cultureservice. The lyrics of the Ahmadiyya's pupujian contain an overview of the arrival of the Mahdi.

There are at least five messages contained in the above Ahmadiyya's pupujian: First, the information that the Mahdi has come to the world. According to Ahmadiyya followers, the Mahdi, who has been waiting for a long time by Muslims has come. His name has also well-known, namely Hazrat Mirza Ghulam Ahmad (1836-1908).

Second, the Mahdi is a descendant of the Sundanese ancestors. The above Ahmadiyya's pupujian also explained that Ghulam Ahmad or the Mahdi is not a stranger. He is basically still a descendant of the Sundanese ancestors. The author of pupujian seems to be greatly influenced by what is called as uga (oracle) among the Ahmadis. They believe that the awaited of Mahdi is in accordance with the Sundanese ancestors' oracle for a long time. Uga or cacandran is an oral tradition in the form of traditional oracles from the ancestors on the arrival of an important change concerning the 
problem of the state or village (Panitia Kamus 1980, 80, 547; Warnaen et al. 1987, 7-9). Uga can meet the Sundanese mystical hopes on a wind of change behind the crisis due to economic pressures and political turmoil with messianic beliefs on the coming of the Mahdi in the Ahmadiyya community. Therefore, the Mahdi is not considered as a stranger. He was essentially still a "descendant" of the Sundanese ancestors because his coming had been predicted by their ancestors. The meaning of the descendants here is not in the sense of the Sundanese cognation, but the successor of Sundanese ancestors teaching which has long been predicted.

Third, the Mahdi simply continued the teachings of the Prophet Muhammad. In addition to the Mahdi who considered as a Sundanese descendant and continues the teachings of their ancestors, he also basically continues the teachings of the Prophet Muhammad. There is an attempt of Sundanese Ahmadiyya to bring together the teachings of the Sundanese ancestors with the teachings of the Prophet Muhammad through the medium of the Mahdi or Ghulam Ahmad. It is a compromise of the Ahmadiyya community in order their teachings can be received well. Instead of being regarded as an outsider teaching, the Ahmadiyya teachings were regarded as the Sundanese ancestral teachings which were inherited from generation to generation. It also becomes a good strategy to bring together both the teachings of the Sundanese ancestors and the Prophet Muhammad. The religious message conveyed in the form pupujian became an important part of the tradition of the Sundanese Ahmadiyya.

Fourth, the Ahmadiyya community responds to those who do not like their teachings. They provide answers to some rejections and hatred for them. The author of pupujian aware that since a long time the arrival of the Ahmadiyya to Indonesia, especially to West Java, has always been rejected by Muslims majority. It is a hatred that received not only at this time. The pupujian indirectly recorded the historical experience of the Ahmadiyya community for a long time ago. They were hated and slandered. However, according to the author, those who hate the Ahmadiyya will eventually be ashamed of themselves. The pupujian described that rather than hate and slander, it is better to learn the Ahmadiyya teachings first. It is an attitude of the Ahmadiyya that even though it has been hated for a long time, they survived until this time. Although they were regarded as deviant and their civil rights were not appreciated by the Indonesia government, the Ahmadiyya were still able to maintain the continuation of their existences until now. The presence of Ahmadiyya is a representation of the history of 
Islam and Indonesian nationalism which tends to be constant, between contestation and agreement with the minority groups. It is a situation that arises where there are contradictions in treating religious categories and describing the paradoxical character of Indonesian nationalism (Bottomley 2015, 1).

Fifth, the pupujian also contains an invitation to follow the Ahmadiyya. This poem and song of praise are closed with a message in the form of an invitation or an appeal to follow the Mahdi and enter into the Ahmadiyya community in order to gain the pleasure of Allah.

Therefore, the Sundanese pupuiian or song of praise on the Mahdi clearly illustrates narratives of the Ahmadis regarding their positions in Sundanese society. It showed the identity of the Sundanese Ahmadiyya who not only dared to inform about the arrival of the Mahdi, but also showed that his arrival came from the descendants of their own ancestors of Sundanese people. The pupujian as a daily song of Ahmadiyya children and youths (ghudam) at the Ahmadiyya mosque is no longer merely teaching, but also a cultural means to strengthen their ideological identities as an Ahmadiyya as well as a Sundanese.

In the context of Sundanese literature, the pupujian of the Mahdi is structurally no different from other Sundanese pupujian. The Ahmadiyya's pupujian uses a kwartét pattern in each stanza consisting of four cantos, eight syllables with the same scheme of ending vowels in each stanza (murwakanti).

The song of praise or pupujian is generally following the rules of poetry in the form of the number of cantos (larik), the number of syllables, and the scheme of ending vowels in each stanza. The number of cantos usually consists of two, four, six to nine arrays in each stanza.

\section{Table 4}

the rule of pupujian

\begin{tabular}{ccc}
\hline cantos & Syllables & ending vowels \\
\hline 4 & 8 & $\mathrm{a}-\mathrm{a}-\mathrm{a}-\mathrm{a}$ \\
& & a-a-b-b \\
\hline 4 & 8 &. \\
\hline
\end{tabular}


The Ahmadiyya's pupujian of the Mahdi consists of four cantos. It is similar to Arabic shi'r. Each stanza consists of four cantos. Its some scheme of ending vowels in each stanza are not the same. There are two types of ending vowels in all of these stanzas. First, all the vowels are finally the same (a-a-a-a); Second, some stanzas using two types of ending vowels (a-a-b-b) (Rusyana 1971, 14-6). The first type appears in the first and last or eighth stanza. The author of pupujian uses the same ending vowels as seen in the words saday(a), sulay(a), atos ay(a), alam duny(a) (first stanza) and sadayan(a), réréncangann(a), sakapendakn(a), and mangpaatn(a) (eight stanza). Meanwhile, the second type appears in the second to seventh stanzas. There is two types of patterns are used for the four cantos. The first pattern on the first and second cantos in the form (a-a) and the second pattern on the third and fourth cantos in the form (b-b). The second stanza, for instance, uses the word masyh(u)r and $\operatorname{luluh}(u) r$ in the first cantos and Ahm(a)d and $\operatorname{Muhamm}(a) d$ in the third and fourth cantos. Both the first ending vowel type that uses the pattern (a-a-a-a) and the ending vowel type that uses two patterns $(a-a-b-b)$ used consistently by the author with all the same eight syllables.

In addition, the Ahmadiyya's pupujian sometimes has the different ending vowels of cantos in the pronunciation, even though the ending vowels are the same. The seventh stanza, for instance, the author uses the word lebet kana Ahmadiyya(a)h with (a) in pronunciation that different with the malar karidoan All(a)h that pronunciation with (o). The author does not try to find the other Sundanese words that are in accordance with the pronunciation of the word "Ahmadiy(a)h" with the ending vowel (a), but use the word "All(a)h" which its ending vowel pronunciation with (o).

The pupujian of the Mahdi basically has the same rules as other types of pupujian which contain teaching or religious advice. One of the differences is the message which contains teachings about the Mahdi in Ahmadiyya teachings. Therefore, the author when composing the pupujian knew the Ahmadiyya teachings well. They just adjust the message into the rules of pupujian.

\section{Why did the Ahmadiyya followers write the Pupujian of the Mahdi?}

The above explanation demonstrated that pupujian learned and sung among Sundanese Ahmadiyya followers. The pupujian is an important instrument in teaching the doctrine of the Mahdi for their followers who 
are Sundanese people. Therefore, this section will explore the driving factors for the use of Sundanese oral literature in the form of pupujian based on psychological and sociological perspectives. This explanation is important to highlight the position of the pupujian in a broader context, especially related to the existence of the Ahmadiyya community in Indonesia.

The majority of Ahmadiyya followers in Indonesia are Sundanese people. Therefore, Sundanese Ahmadiyya followers are internally very familiar with the tradition of pupujian that is inherited from generation to generation. In addition, the Ahmadiyya followers who generally live in the countryside and use Sundanese language as their mother language, so that oral traditions of pupujian are still to be alive and developing in Ahmadiyya mosques. The tradition of pupujian as part of a cultural tradition is easily maintained by them.

In addition to the internal factors of Sundanese culture that lived in the Ahmadiyya community, the integration of the teaching of the Mahdi into Sundanese oral literature is also important in the context of psychological viewpoint. This related to the reason why did the followers of the millenarianism movement of Ahmadis lost their confidence in facing the situation. They finally believe in the promises of glorified social change by expecting the coming of the Mahdi. Some scholars use the notion of relative deprivation as an important factor in the emergence of the movement. It also relates to the tension caused by the gap between their ideas and the reality of collective satisfaction. The community who economically and politically marginalized is not easily drawn to leave their sufferings. Living in a shortage is clear and measurable. It is something that considered as relative and uncertain for the imagination and experience of the others. This is what drives the community to make efforts to change their lives (Lindstrom 2002, 562).

The Sundanese Ahmadis who are generally lived in the countryside of Sunda regions are in a situation of suffering and misfortune. This is not only relating to the economic pressure, the opposition of the Muslims majority, and the incompatibility of political promises of the government in maintaining religious freedom (Beck 2005, 210-46; Suryana 2017, 71-104; Ropi 2010, 281-320; Rahman 2014, 408-22). However, culturally Sundanese people feel the loss of guardian of Sundanese culture for a long time. There was a kind of wishful thinking for a life in which the glory days of the Sundanese had been achieved during the time of Prabu Siliwangi, a 
Sundanese greatest king. Since the defeat of the Sundanese empire in the sixteenth century, Sundanese people have lost their guardian traditions (Ekadjati 2009, 84, 116). There is a formation of personality that is connected with the glory of Sundanese people in the future. There are wishes and hopes of Sundanese people in the past to emerge a Sundanese leader who was able to bring their people into glory. The hopes of the wind of change into Sundanese glory reflected in Ahmadiyya's pupujian of the Mahdi.

Therefore, the pupujian of the Mahdi in the Sundanese Ahmadiyya has an important position both psychologically and politically. The Ahmadiyya's waiting of arrival of the Mahdi who will eliminate the difficulties of life patiently is part of religious piety. It is a continuous rejection of the various difficulties that felt by the Sundanese people. The situation that is expected will happen after the arrival of Imam Mahdi is not much different from the glory of the Sundanese people under the Sundanese kingdom of Prabu Siliwangi. Meanwhile, the belief in the coming of the Mahdi can encourage Ahmadiyya followers to strive towards a life that is aspired in the future.

Ahmadiyya's belief in the Mahdi individually can provide psychological comfort for Ahmadiyya followers. It will provide internal strength to be ready to face various difficulties and give hope for a better future. Finally, the belief in the existence of the Mahdi will give an idea of the purpose of life that can lead Ahmadiyya followers to remain faithful in their paths. In addition, their beliefs in the Mahdi collectively can be considered as a force that helps their social lives. Al-Mahdî is believed to be constantly present in the lives of Ahmadis. Their beliefs in al-Mahdî became the basis for a collective consciousness that contributes to social solidarity among Ahmadiyya followers. The social solidarity of Ahmadis is generally realized during social and political crises. It was present at the time of the crisis, especially when the crisis cannot be overcome so that there was uncertainty in facing the future (Maryam 2012, 230).

There are some reasons why their hopes for the messianism arose. Ahmadiyya followers feel frustration after failed in their goal attainments. The reaction that arises from the Ahmadis is a social-political change that leads to the resistance. The messianism belief that promises victory with divine assistance becomes a contextual answer in such a situation.

Other scholars use a sociological perspective to read the millenarianism movement of the Sundanese Ahmadiyya. The movement 
seeks the similarity of understanding in the community and the dynamics of life among their followers, as well as in a wider social context that influences in achieving their goals. The pupujian of the Mahdi sociologically becomes the social adhesive of Ahmadiyya followers to fight for their goals together.

In addition, the millenarianism movement of Sundanese Ahmadiyya sociologically also shows the failure of the control mechanism by the authorities and the Muslims majority. They usually release the political actions that challenge the prevailing social rules. These various controls unfold from the physical pressure to soft daily actions. The milenarianism movement of Sundanese Ahmadiyya has the best chance in organizing, expanding and even destabilizing the rules when the prevailing policy mechanism failed (Lindstrom 2002, 562).

It is not only internal factors, but the use of pupujian of the Mahdi in Sundanese Ahmadiyya externally is also related to the teachings of the Caliph or hudhur. He ordered the Ahmadiyya followers to disseminate the teachings of the Ahmadiyya all over the world in many languages. According to the followers of the Sundanese Ahmadiyya, it is a necessity to use Sundanese language and culture as a means of disseminating the Ahmadiyya teachings. The use of pupujian also cannot be separated from the cultural negotiations of the Ahmadis facing the Muslims majority. The Ahmadis try to prove that the teachings of the Ahmadiyya have a conformity value with Sundanese culture, although they are considered by other Muslims to bring new teaching and deviate from Islam.

\section{The Pupujian of the Mahdi and Sundanese Ahmadiyya Identity}

Sundanese Ahmadiyya's pupujian of the Mahdi, anthropologically cannot be separated from the acculturation of culture in Sundanese society. It is a social process that arises when Sundanese people face external teaching on the Mahdi. The teaching was accepted gradually into the Sundanese culture. The Sundanese people did what Cak Nur called "reciprocal acculturation" between Sundanese culture in the form of pupujian and Ahmadiyya teachings on Mahdiism (Madjid 1995, 550). The Ahmadiyya teachings are gradually accepted into the Sundanese tradition in the form of pupujian. The coming of Ahmadiyya change the Sundanese society and transfer the social forms into a better situation. However, the coming of the Ahmadiyya, at the same time, was not regarded as a 
reduction the Sundanese tradition from its past. It can also help preserve whatever is considered good from the past and can be maintained within the framework of Ahmadiyya teachings.

In the actual context, the pupujian of the Mahdi cannot be separated from what is called as an effort to acculturate the identity and accommodate the Ahmadi resistance against various forms of oppression (Connley 2016, 49). The marginalization of the Ahmadiyya community is a relational connection rather than an essential one because the agency is a specific person and context. In addition to the voices of the Ahmadiyya resistance efforts towards the government and other Muslim groups, there are also the Ahmadiyya agencies who are trying secretly to look for situations and issues that lead to a situation of harmony among various parties as a strategy to manage their controversial identities. Their efforts to harmonize identity through the pupujian become a strategy of problem-solving taken by Ahmadis to live peacefully and stay connected with other Sundanese Muslims. The Ahmadiyya followers encourage the harmony between Sundanese culture and the teachings of Ahmadiyya as part of efforts to maintain connectivity with the others and share their identities as fellow Sundanese. The Ahmadiyya community seemed to avoid the possible negative reactions of other Sundanese people through the efforts to share their identities.

Sundanese Ahmadiyya then makes some efforts to modify their teachings in order to realize harmony and avoid various rejections. Their teachings on the Mahdi as if hidden behind the form of accommodation towards Sundanese tradition of the pupujian. Sundanese Ahmadiyya like other Sundanese people demonstrates a pious Islam in respecting the local values. Therefore, the strategy of hidden identities of the Mahdi teaching behind the pupujian can be part of the defense strategy of Ahmadiyya to share their identities with other Sundanese Muslims. It seemed to limit the attitude of their followers when interacting with non-Ahmadis, although basically, it did not show any change in their feelings as Ahmadis.

This can be considered as part of the strategy in order to prevent various threats in a community that still dominated by Sundanese traditions. Ahmadiyya followers, especially from the older generation, maintain their beliefs on the Mahdi through traditional channels such as the pupujian in relation to non-Ahmadis facing various challenges. This is an important effort to share an understanding of their religious identity which is inseparable from the locality of Sundanese traditions. The 
Ahmadiyya community tries to encourage harmony among the Sundanese people, both Ahmadis, and non-Ahmadis. They make serious effort to achieve their goals apart from various oppressions. They do not make an effort to isolate themselves from other Muslim communities but instead demonstrate the openness as part of a strategy to share both Sundanese and Islamic identity in accordance with the nature of the culture in which they live.

The millenarianism movement as reflected in the Sundanese Ahmadiyya's pupujian of the Mahdi is a manifestation of the community and its strong structure. The community is not bounded by the boundary of the region and on the contrary laying on egalitarian and unstructured bonds. This community potentially emerge the symbols and metaphors. They will produce art and religion than law and political structure. The followers of the millenarian movement often reduce their identities to the same level of status outside the leader. They wear similar clothes accompanied by full obedience to the leader and his commands which are considered sacred (Bowie 2001, 170-2).

\section{Conclusion}

This study focuses on the pupujian or song of praise of the Mahdi in the tradition of Sundanese Ahmadiyya in West Java. Pupujian generally has an important position in the traditions of Sundanese people. It is not only used as a means of Islamic teaching but also one of the traditions at pesantren which still lives in Sundanese society. Therefore, its role cannot be ignored in strengthening the cultural identity of Sundanese Islam in West Java.

Pupujian was then adapted and acculturated by Ahmadiyya followers into the teachings of Ahmadiyya. The Ahmadiyya community uses the pupujian as part of a cultural strategy in disseminating the Ahmadiyya teachings and maintaining their existences. The teachings of the Ahmadiyya are easily accepted by Sundanese people, because of the internal element of Ahmadiyya teachings as well as the pupujian as one of the channels of Sundanese culture. Therefore, Sundanese people can accept the Ahmadiyya teachings without losing their religious aesthetic. The pupujian of Imam Mahdi atos lungsur (the Mahdi has come), for instance, is one of the popular pupujians in the tradition of Sundanese Ahmadiyya. 
The pupujian of the Mahdi has an important role in the adaptation and acculturation of Ahmadiyya teachings in Sundanese society. The pupujian is then used as a frame of the Ahmadiyya movement in maintaining their existences and cultural identities as a Sundanese. They continuously produce and reconstruct their identities into a system of sign and symbol or representing themselves against the others. It is an identity that built through a representation of the same as well as a different culture.

The significance of this study is exposing the Sundanese local cultural strategy used by the Ahmadiyya minority. The pupujian of the Mahdi is part of a cultural strategy that faces various accusations of deviation from Muslims majority. It has become the peculiarity of the identity of Ahmadiyya in the Indonesian archipelago which tends to be unique and different from other forms of Ahmadiyya culture in different regions. It is an important contribution of the Sundanese Ahmadiyya to the Sundanese local culture.

\section{References}

Alfitri. 2008. "Religious Liberty in Indonesia and the Rights of 'Deviant' Sects." Asian Journal of Comparative Law 3(1): 1-27.

DOI: https://doi.org/10.1017/S2194607800000144

As'ad, Muhammad. 2009. "Ahmadiyah and the Freedom of Religion in Indonesia." Journal of Indonesian Islam 3(2): 310-413.

DOI: $10.15642 / J I I S .2009 .3 .2 .390-413$

Azra, Azyumardi. 2005. "Pengantar." In Iskandar Zulkarnain. Gerakan Ahmadiyah di Indonesia. Yogyakarta: LKiS.

Beck, Herman L. 2005. "The Rupture of Ahmadiyya with Muhammadiya." Bijdragen tot de Taal, Land-en Volkenkunde 161(2/3): 210-46.

Bottomley, Daniel C. 2015. "The KTP Quandary: Islam, the Ahmadiyya, and the Reproduction of Indonesian Nationalism." Contemporary Islam 9(1): 1-16.

DOI: https://doi.org/10.1007/s11562-014-0302-2

Bowie, Fiona. 2001. The Anthropology of Religion, An Introduction. Oxford: Blackwell Publishers. 
Breidlid, T. 2013. "The Legitimization of Violence Against the Ahmadiyya Community in Indonesia." Kawistara: Jurnal Ilmiah Sosial dan Humaniora 3(2): 165-77.

DOI: https://doi.org/10.22146/kawistara.3979

Burhani, Ahmad Najib. 2013. "When Muslims are not Muslims: the Ahmadiyya Community and the Discourse on Heresy in Indonesia." Ph.D. Thesis. University of California.

Burhani, Ahmad Najib. 2014a. "The Ahmadiyya and the Study of Comparative Religion in Indonesia: Controversies and Influences." Islam and Christian-Muslim Relations 25(2): 141-58.

DOI: https://doi.org/10.1080/09596410.2013.864191

Burhani, Ahmad Najib. 2014b. "Hating the Ahmadiyya: the Place of 'Heretics' in Contemporary Indonesian Muslim society." Contemporary Islam 8(2): 133-52.

DOI: https://doi.org/10.1007/s11562-014-0295-x

Burhani, Ahmad Najib. 2014c. "Conversion to the Ahmadiyya in Indonesia: Winning Hearts Through Ethical and Spiritual Appeals." Sojourn: Journal of Social Issues in Southeast Asia 29(3): 657-90.

Burhani, Ahmad Najib. 2014d. "Treating Minorities with Fatwa: a Study of Ahmadiyya Community in Indonesia." Contemporary Islam 8(3): 285-301.

DOI: https://doi.org/10.1007/s11562-013-0278-3

Connley, Aleah. 2016. "Understanding the Oppressed: A Study of the Ahmadiyah and Their Strategies for Overcoming Adversity in Contemporary Indonesia." Journal of Current Southeast Asian Affairs 35(1): 29-58.

Del Re, Emanuela C. 2014. "Approaching Conflict the Ahmadiyya way: The Alternative Way to Conflict Resolution of the Ahmadiyya Community in Haifa, Israel." Contemporary Islam 8(2): 115-31. DOI: https://doi.org/10.1007/s11562-014-0294-y

Ekadjati, Edi S. 2009. Kebudayaan Sunda Zaman Pajajaran, vol. 2. Jakarta: Pustaka Jaya.

Hasyim, Syafiq. 2017. "The Council of Indonesian Ulama (MUI) and 'aqida-Based Intolerance: A Critical Analysis of Its Fatwa on 
Ahmadiyah and 'Sepilis." In Religion, Law and Intolerance in Indonesia, eds. Tim Lindsey and Helen Pausacker. London and New York: Routledge, 211-33.

Heryani, Yani. 2005. "Metode Penerjemahan Al-Quran dan Kitab Kuning ke dalam Bahasa Sunda." In Pergumulan Islam dengan Kebudayaan Lokal di Tatar Sunda, eds. Cik Hasan Bisri et al. Bandung: Kaki Langit.

Hicks, Jacqueline. 2014. "Heresy and Authority: Understanding the Turn Againts Ahmadiyah in Indonesia." Southeast Asia Research 22(3): 321-39.

DOI: https://doi.org/10.5367/sear.2014.0216

Lathan, Andrea. 2008. "The Relativity of Categorizing in the Context of the Ahmadiyya." Die Welt des Islams 48(3): 372-93.

DOI: https://doi.org/10.1163/157006008X364749

Lindstrom, Lamont. 2002. "Millenial Movement, Millenarianism." In Encyclopedia Social and Cultural Anthropology, eds. Alan Barnard and Jonathan Spencer. London \& New York: Routledge.

Madjid, Nurcholish. 1995. Islam Doktrin dan Peradaban: Sebuah Telaah Kritis tentang Masalah Keimanan, Kemanusiaan, dan Kemodernan. Jakarta: Yayasan Wakaf Paramadina.

Ma'mun, Titin N. 2011. "Pola Rima Syi'iran dalam Naskah di Tatar Sunda dan Hubungannya dengan Pola Syair Arab.” Jurnal Manassa 1(1): 147-59.

Ma'mun, Titin N. 2009. "Kontribusi Islam dalam Sastra Sunda (Kajian Ilmu 'Arudl)." Jurnal Lektur Keagamaan 7(2): 235-52.

Manshur, Fadhil Munawwar. 1999. "Tasawuf dan Sastra Tasawuf dalam Kehidupan Pesantren." Humaniora 11(1): 102-109.

DOI: https://doi.org/10.22146/jh.v11i1.631

Maryam, Siti. 2012. Damai dalam Budaya, Integrasi Tradisi Syi'ah dalam Komunitas Ahlusunnah wal Jama'ah di Indonesia. Jakarta: Balitbang Diklat Puslitbang Lektur dan Khazanah Keagamaan Kementerian Agama RI. 
Matin, Usep Abdul. 2009. "K.H. Ahmad Sanusi (1888-1950): His ReligioIntellectual Discourse, and His Work Collection." Lektur 7(1): 14764.

Menchik, Jeremy M. 2011. "Tolerance Without Liberalisme: Islamics Institutions and Political Violence in Twentieth Century Indonesia." Dissertation. University of Wisconsin-Madison.

Nasr, Seyyed Hossein. 1987. Traditional Islam in the Modern World. London and New York: Kegan Paul International.

Nurjamin, Asep. 2005. "Cigawiran: Tembang Sunda dari Pesantren.” In Pergumulan Islam dengan Kebudayaan Lokal di Tatar Sunda, eds. Cik Hasan Bisri et.al. Bandung: Kaki Langit.

Pamungkas, Cahyo. 2015. "Social Resilience of Minority Group: Study on Shia Refugees in Sidoarjo and Ahmadiyya Refugees in Mataram." Ulumuna: Journal of Islamic Studies 19(2): 251-78.

DOI: https://doi.org/10.20414/ujis.v19i2.418

Panitia Kamus Lembaga Basa \& Sastra Sunda. 1980. Kamus Umum Basa Sunda. Bandung: Penerbit Tarate.

Patzold, Uwe U. 2011. "Self-Depense and Music in Muslim Contexts in West Java." In Divine Inspirations: Music and Islam in Indonesia, eds. David D. Harnish and Anne K. Rasmussen. New York: Oxford University Press.

Rahman, Fatima Zainab. 2014. "State Restrictions on the Ahmadiyya Sect in Indonesia and Pakistan: Islam or Political Survival?." Australian Journal of Political Science 49(3): 408-22.

DOI: https://doi.org/10.1080/10361146.2014.934656

Rahman, Fazlur. 1997. Islam. Trans. Ahsin Mohammad. Bandung: Pustaka.

Rasmussen, Anne K. 2010. Women, the Recited Qur'an, and Islamic Music in Indonesia. London: University of California Press.

Rohmana, Jajang A. 2013. "Makhtutat Kinanti [Tutur teu Kacatur Batur]: Tasawwuf al-Alam al-Sundawi "ind al-Hajj Hasan Mustafa (18521930)." Studia Islamika 20(2): 325-75.

DOI: https://doi.org/10.15408/sdi.v20i2.390 
Rohmana, Jajang A. 2015a. "Terjemah Puitis Kitab Suci di Jawa Barat:

Terjemah Al-Qur'an Berbentuk Puisi Dangding dan Pupujian Sunda."

Suhuf: Jurnal Pengkajian al-Qur'an dan Budaya 8(2): 175-202.

Rohmana, Jajang A. 2015b. "Sastra Sufistik Melayu dan Sunda di Nusantara: Mempertemukan Hamzah Fansuri dan Haji Hasan Mustapa." Ibda': Jurnal Kebudayaan Islam 13(1): 1-27.

DOI: https://doi.org/10.24090/ibda.v13i1.486

Rohmana, Jajang A. 2015c. "Metrical Verse as a Rule of Qur'anic Translation: Some Reflections on R.A.A. Wiranatakoesoema's Soerat Al-Baqarah (1888-1965)." Al-Jami'ah: Journal of Islamic Studies 53(2): 439-67.

DOI: https://doi.org/10.14421/ajis.2015.532.439-467

Romli H.M., Usep. 2005. "Pesantren sebagai Pusat Budaya Orang Sunda." In Pergumulan Islam dengan Kebudayaan Lokal di Tatar Sunda, eds. Cik Hasan Bisri et al. Bandung: Kaki Langit.

Ropi, Ismatu. 2010. "Islamism, Government Regulation, and the Ahmadiyah Controversies in Indonesia." Al-Jami'ah: Journal of Islamic Studies 48(2): 281-320.

DOI: https://doi.org/10.14421/ajis.2010.482.281-320

Rosidi, Ajip. 2009. Gerakan Kasundaan. Bandung: Kiblat.

Rosidi, Ajip. 2011. Sawer jeung Pupujian. Bandung: Kiblat.

Rusyana, Yus. 1971. Bagbagan Puisi Pupujian Sunda. Bandung: Projek Penelitian Pantun dan Folklore Sunda.

Sadkar, 2015. Tanda-tanda Ahir Zaman: Maluruh Kasumpingan Isa Almasih $\mathcal{E}$ Imam Mahdi Nu Dijangjikeun sarta Tanda-tanda Kasumpinganana. Bogor: Neratja Press.

Scherpen, Bastiaan. 2015. "Enforcing Religious Freedom in Indonesia, Muslim Elites and the Ahmadiyah Controversy after the 2011 Cikeusik Clash." In Islam, Politics and Change, The Indonesian Experience after the Fall of Suharto, eds. Kees van Dijk and Nico J.G. Kaptein. Leiden: Leiden University Press. 
Soedirgo, Jessica. 2018. "Informal Networks and Religious Intolerance: Clientelism Incentivizes the Discrimination of the Ahmadiyah in Indonesia." Citizenship Studies 22(2): 191-207. https://doi.org/10.1080/13621025.2018.1445490

Sofianto, Kunto. 2014. "Tinjauan Kritis Jemaat Ahmadiyah Indonesia." Dissertation. Universitas Kebangsaan Malaysia.

Suryana, A'an. 2017. "Discrepancy in State Practices: The Cases of Violence against Ahmadiyah and Shi'a Minority Communities during the Presidency of Susilo Bambang Yudhoyono." Al-Jami'ah: Journal of Islamic Studies 55(1): 71-104.

DOI: https://doi.org/10.14421/ajis.2017.551.71-104

Syaqiq, Sholihin. 2009. Kumpulan Khutbah ku Basa Sunda. Bandung: Sinarbaru Algesindo.

Warnaen, Suwarsih et al. 1987. Pandangan Hidup Orang Sunda Seperti Tercermin dalam Tradisi Lisan dan Sastra Sunda. Bandung: Depdikbud Dirjen Kebudayaan Bagian Proyek Penelitian dan Pengkajian Kebudayaan Sunda.

Wilar, Abraham Silo. 2015. "Khatamul Anbiya According to Ahmadiyya in Indonesia, A History of Interpretation.” Dissertation. Universitas Gajah Mada Graduate School.

Yahya, Iip Zulkifli. 2009. "Ngalogat di Pesantren Sunda: Menghadirkan yang Dimangkirkan.” In Sadur: Sejarah Terjemahan di Indonesia dan Malaysia, ed. Henri Chambert-Loir. Jakarta: KPG.

Yahya, Iip Zulkifli. 2008. Ajengan jeung Santrina Pasantren Salafiyah di Jawa Barat. Bandung: Puspawarna.

Yahya, Iip Zulkifli. 2003. "Tradisi Ngalogat di Pesantren Sunda, Penemuan dan Peneguhan Identitas." In Politik dan Postkolonialitas di Indonesia, ed. A. Budi Susanto. Yogyakarta: Penerbit Kanisius.

Zulkarnain, Iskandar. 2005. Gerakan Ahmadiyah di Indonesia. Yogyakarta: LKiS.

Interview with $\mathrm{Mr}$. B, one of Ahmadiyya followers in Manislor Kuningan, Friday, November 27, 2015 at 09.30. 
Interview with Mr. R, Sadkar's grandson, Sadkar is a founder of Ahmadiyya branch in Garut, Pataruman, Tarogong Garut, Tuesday, August 16, 2016 at 11.00 . 